\title{
ENTREVISTA
}

\section{Masones y masonería en México, 1760-1936}

El investigador Marco Antonio Flores Zavala ha defendido una Tesis doctoral, cuyo título es "Masones y masonería en México, 1760-1936" en la Universidad Jaume I en Castellón, España, en enero de 2016. El autor es ciudadano mexicano, nació en 1970.

¿Cuáles fueron los motivos que le llevaron a enfocar su investigación hacia la Masonería?

Desde mi tesis de maestría, que realicé en El Colegio de Michoacán (México), inicié la exploración a la masonería. Entonces revisé a los masones-políticos de fines del siglo XIX en la provincia mexicana de Zacatecas. Para la investigación doctoral me pareció pertinente estudiar las masonerías establecidas en el territorio mexicano, y no centrarme en un grupo o una región, sino en las diferentes obediencias que laboraron y quizá laboran en México.

El fin general de la última investigación era presentar un panorama de los masones y la masonería, los ciclos propios de la institución, sus intervenciones en el espacio público y las disputas políticas en las que participaron los masones mexicanos en un amplio período: 1760-1936, del año que existe indicios de la institución a los años en que las logias son parte del sistema político mexicano.

¿Cuáles fueron las fuentes que ha utilizado?

De todo tipo. Desde la documentación que produjeron los masones en sus labores en logias; papeles que publicaron detractores de la masonería; y la bibliografía que presenta a la institución como un objeto de estudio. Respecto de la documentación masónica, tuve la oportunidad de acceder a bibliotecas y acervos gubernamentales (como la Biblioteca Nacional, los archivos históricos de Zacatecas y Aguascalientes, y el General de la Nación) y también privados, estos de algunas las obediencias regionales asociadas en la Confederación de Grandes Logias Regulares de México.

En lo que toca a la bibliografía para tener rutas e ideas, me fue y es de apoyo infinito las actas de los diferentes Simposios del Centro de Estudios Históricos de la Masonería Española, los cuales dirige el doctor José Antonio Ferrer Benimeli. También está su revista $R E H M L A C+$, que está dando vuelco en las formas de estudiar la masonería en el orbe occidental, en especial en Hispanoamérica.

Agregaría otra fuente hecha en el trabajo de campo, pues visite algunos lugares donde laboraron los masones; concurrí para conocer monumentos financiados o construidos por ellos; otro recurso indiciario es el arte funerario en los panteones decimonónicos, 
aunque esto trabajé poco y apenas lo refiero en el ensayo leído como tesis.

¿Cuáles fueron las principales dificultades con las que se ha encontrado? ¿Cómo las ha superado?

La principal, imagino que a varios historiadores nos ocurrió, es el acceso a los acervos de las masonerías. Para estudiar este tema se debe contar con información propia del "hecho masónico". Otro asunto es y fue el cómo estudiar la masonería. Pude avanzar merced a la asesoría del doctor Manuel Chust, mi asesor en la Universidad Jaume I; a las recomendaciones del doctor José Antonio Ferrer Benimeli; y a las sugerencias de los colegas que estudian el tema, sobre todo en los Simposios del CEHME.

¿Cuáles fueron las principales problemáticas históricas que su trabajo ha resuelto?

Revindico dos. La primera es proponer la delimitación de las etapas de la francmasonería en México. Justifico: es erróneo considerar que es continua o es lo mismo en todo el siglo XIX. Pues fueron y se practicaron diferentes ritos, obediencias y múltiples reglamentos que nos indican que la institución debe contextualizarse desde su vida interna. Teniendo en cuenta eso, se expuso que hay diferentes fases que no necesariamente son los ciclos políticos del país (en el caso de México Independencia, Reforma, Porfiriato y posrevolución).

Cito las fases propuestas: introducción y presentación de la francmasonería en el siglo XVIII. En esta etapa no hay masones, hay más una presentación en la esfera de lo público de las anti masonerías de la Corona y la Iglesia. Luego está la masonería primigenia que entre las décadas de 1820 y 1860 ocurrió el establecimiento de logias de los ritos escocés y del yorkino; también fue la fase de labores del denominado Rito Nacional Mexicano, el cual estuvo activo en esos años y los siguientes.

Una tercera etapa es la que va de 1860 a 1900 - una fase de institucionalización (organización conforme a la reglamentación tradicional) y de centralización (la procuración de las direcciones se establecieran en la ciudad de México, en detrimento de las grandes logias estatales -, en ésta se establecieron las logias reconocidas internacionalmente de los grados filosóficos, las logias del rito escocés y se mantuvo la del Nacional Mexicano. Entonces se proyectó una organización que armonizaba las labores de los talleres mexicanos con los europeos y estadunidenses; también hubo planes de centralización en una gran logia con políticos influyentes como dirigentes de la asociación. La cuarta etapa iría de 1900 a 1936, en ella siguió una fuerte dinámica de los masones, quienes estuvieron en la política, en empresas que dieron el rostro del progreso a los regímenes porfiriano y posrevolucionario y en los institutos científicos de las provincias (estas son los antecedentes de las universidades de cada provincia). 
Otro asunto es presentar las redes sociales y las sociabilidades masónicas como una de las formas que hicieron sociedad civil y política en el país. A los masones se les localiza como ciudadanos políticos principales, pero también podemos situarlos como actores de viejo y nuevo cuño cultural; como profesores de educación superior; como parte de las elites provincianas e integrantes de las extensas redes sociales mexicanas.

¿Podría resumir la esencia de su Tesis?

En el trayecto del texto interrogamos qué fue la masonería (Grandes logias, logias, masones, ceremonias, lecturas y nexos entre masones y confrontaciones al exterior de la asociación) establecida en México durante los siglos XIX y XX. Examinamos qué se sabía, cómo se divulgó la existencia de la francmasonería y los motivos de su prohibición (secreto, juramento y fines ocultos posiblemente en contra del Estado y la Iglesia).

Sostenemos que en la Nueva España no hubo masonería. Para este aserto mostramos que la logia (lugar) como parte de la masonería, debe estar acondicionada para las ceremonias y la concurrencia de los masones; luego, sino hay ceremonias conforme a las normas de la francmasonería, las reuniones sólo son sociabilidades de masones. Un masón no es sinónimo de masonería. Lo que sí circuló fueron las prohibiciones romanas, inquisitoriales y reales. En el reino novohispano lo que se conoció fue de masones, presuntos masones y algunos objetos. Las denuncias fueron hechas ante la Inquisición y autoridades reales. En este tenor se revisaron los medios de presentación.

Planteamos que la masonería, pese a la reglamentación casi inamovible desde el siglo XVIII, y admitido en México, las relaciones de dominación no fueron privilegiadamente formales y legales. Siendo una relación social, no privilegiamos al individuo moderno; miramos las formas de organización: ritos masónicos y grandes logias, logias y masones. Y, pese a la vinculación con la esfera política, la masonería y los masones pueden examinarse desde su organización, sus ideas y su interacción en las comunidades donde están asentadas las logias.

Consideramos que la masonería no sólo fue un frente político o una escuela cívica, sino un espacio que proyectó modelos de organización y configuración de prácticas culturales. Lo asentado permite configurar otras preguntas, señalamos: Formas económicas de manutención de las logias, toda vez la orden de impedir la existencia de mecenazgos y patronazgos. Cómo fue el financiamiento y el destino de lo recaudado. Y Las fuentes informativas en las que abrevaron los masones que configuraron otras organizaciones masónicas. Permite interrogar ¿Cómo fueron las relaciones internacionales, cuáles eran los fines de sostener vínculos con logias de otros países? 
¿Cuáles fueron las lecciones, a todos los niveles, personal y profesional, que usted ha deducido de su experiencia investigativa?

Tener disciplina; advertir otras líneas de nuevas investigaciones sobre el "hecho masónico" ¿Ahora, cuáles son sus proyectos profesionales?

Luego de leer la tesis, debo y en ello estoy, reelaborando partes del documento para ver si es publicable. Estoy pues leyendo y reflexionado.

Esta entrevista se efectúo de forma telemática el 31 de marzo de 2016.

Autores de la entrevista: Ricardo Martínez Esquivel e Yván Pozuelo Andrés, Director y Editor de REHMLAC+.

DOI: http://dx.doi.org/10.15517/rehmlac.v8i1.24281 